\title{
Dietary microbial phytase exerts mixed effects on the gut health of tilapia: a possible reason for the null effect on growth promotion
}

\author{
Jun $\mathrm{Hu}^{1,2}$, Chao $\mathrm{Ran}^{2}$, Suxu $\mathrm{He}^{2}$, Yanan $\mathrm{CaO}^{2}$, Bin $\mathrm{YaO}^{2}$, Yuantu Ye ${ }^{3 *}$, Xuezhen Zhang ${ }^{1 *}$ \\ and Zhigang Zhou $^{2 *}$ \\ ${ }^{1}$ College of Fisheries, Huazhong Agricultural University, Wuban, Hubei Province 430070, People's Republic of China \\ ${ }^{2}$ Key Laboratory for Feed Biotechnology of the Ministry of Agriculture, Feed Research Institute, Chinese Academy of \\ Agricultural Sciences, No. 12 Zhongguancun South St., Beijing 100081, People's Republic of China \\ ${ }^{3}$ School of Biology \& Basic Medical Sciences, Soochow University, Suzhou, Jiangsu 215123, People's Republic of China \\ (Submitted 19 August 2015 - Final revision received 18 February 2016 - Accepted 2 March 2016 - First published online 15 April 2016)
}

\section{Abstract}

The present study evaluated the effects of dietary microbial phytase on the growth and gut health of hybrid tilapia (Oreochromis niloticus $\$ \times$ Oreochromis aureus $\delta$ ), focusing on the effect on intestinal histology, adhesive microbiota and expression of immune-related cytokine genes. Tilapia were fed either control diet or diet supplemented with microbial phytase (1000 U/kg). Each diet was randomly assigned to four groups of fish reared in cages $(3 \times 3 \times 2 \mathrm{~m})$. After 12 weeks of feeding, weight gain and feed conversion ratio of tilapia were not significantly improved by dietary microbial phytase supplementation. However, significantly higher level of P content in the scales, tighter and more regular intestinal mucosa folds were observed in the microbial phytase group and the microvilli density was significantly increased. The adhesive gut bacterial communities were strikingly altered by microbial phytase supplementation $(0 \cdot 41<$ similarity coefficient $<0 \cdot 54)$. Stimulated intestinal inflammation and stress status were observed in the fish fed diet supplemented with microbial phytase, as indicated by the up-regulated intestinal expressions of the cytokine genes $(\operatorname{tnf}-\alpha$ and $\operatorname{tg} f-\beta)$ and $h s p 70$. In addition, the gut microvilli height was significantly decreased in the phytase group. These results indicate that dietary microbial phytase may exert mixed effects on hybrid tilapia, and can guide our future selection of phytases as aquafeed additives - that is, eliminating those that can stimulate intestinal inflammation.

Key words: Microbial phytase: Gut: Adhesive bacteria: Cytokines: Tilapia

The replacement of fishmeal by plant protein sources is of great interest in aquafeed industry ${ }^{(1,2)}$. However, approximately $70 \%$ of the total P in plant feedstuffs is bound as phytate, which is poorly available for monogastric or agastric aquatic animals because of the absence of phytase in their gut for efficient phytate hydrolysis ${ }^{(3,4)}$. The presence of phytate in the aquafeed may also negatively affect growth performance, nutrient and energy utilisation and mineral uptake of fish ${ }^{(5)}$. Furthermore, the undigested phytate-P ends up being excreted into the water, which may cause $\mathrm{P}$ pollution of the aquatic environment ${ }^{(6)}$.

Bound phytate-P can be effectively converted to available-P by phytase ${ }^{(6)}$. During the last decade, microbial phytase has been used by aquafeed industries to neutralise the negative effects of phytate ${ }^{(5)}$. Dietary microbial phytase supplementation has been reported to improve the $\mathrm{P}$ bioavailibility ${ }^{(7-13)}$, mineral utilisation $^{(3,12,14-17)}$, protein digestibility ${ }^{(7,11,18)}$ and growth performance $^{(3,8,12,15,16,19-21)}$ in different fish species. In addition, phytase can decrease $\mathrm{P}$ excretion into the aquatic environment $^{(22)}$. In Nile tilapia, supplementation of microbial phytase at $1000 \mathrm{U} / \mathrm{kg}$ feed resulted in growth and mineral utilisation similar to that of a plant-based diet supplemented with inorganic $\mathrm{P}^{(12,23,24)}$.

Studies about microbial phytase supplementation in aquafeed have mainly focused on the effect on nutrient utilisation and fish growth performance, the dose-response, efficacy of phytases from different sources and the most efficient ways of supplementation $^{(5,6,9,11,12,23,25)}$. However, as a feed-additive enzyme, microbial phytase may modulate the gut microbiota through the hydrolysis of phytate, and thus influence the gut health. Smulikowska et al. ${ }^{(26)}$ reported higher levels of acetic and butyric acids in caecal contents of broiler chickens fed phytase, suggesting a modulation of the microbial activity due to more $\mathrm{P}$ and other nutrients released from phytates. In pigs, supplemental phytase was observed to increase the Clostridium group in the ileum without changing total bacterial numbers ${ }^{(27)}$. However, there has been no study about the effect of microbial

\footnotetext{
Abbreviation: $C s$, similarity coefficient.

* Corresponding authors: Y. Ye, fax +86 5126588 0179, email yeyuant@pub.sz.jsinfo.net; X. Zhang, fax +86 2787282114 , email xuezhen@mail.hzau.edu.cn;

Z. Zhou, fax +861082106054, email zhou_zg@msn.com
} 
phytase on gut health of fish. Therefore, the main purpose of our study was to evaluate the impact of microbial phytase on gut health of fish, focusing on the effect on intestinal histology, adhesive microbiota and the expressions of stress-related gene markers and inflammation-related cytokine genes. Hybrid tilapia (Oreochromis niloticus $\$ \times$ Oreochromis aureus $\left.{ }^{\top}\right)$ was selected as the experimental target because of its strong environmental adaptability, ease of breeding and high socio-economic importance in both developing and developed countries $^{(28)}$.

\section{Methods}

\section{Fish and diet}

The microbial phytase (derived from strain Aspergillus niger 963, expressed by Pichia pastoris, $5 \times 10^{5} \mathrm{U} / \mathrm{ml}$ culture medium) was obtained from Challenge Group (Beijing, China). Juvenile hybrid tilapia (O. niloticus $\$ \times O$. aureus $\sigma^{*}$ ) were raised in the tilapia breeding base of Jiaxing (Zhejiang, China). The basal diet (diet 1) was formulated according to the recommendations for tilapia ${ }^{(29)}$, and the treatment group (diet 2) contained $1000 \mathrm{U} / \mathrm{kg}$ microbial phytase (supplementation of microbial phytase from 500 to $1500 \mathrm{U} / \mathrm{kg}$, especially $1000 \mathrm{U} / \mathrm{kg}$ of feed, led to improved growth, mineral utilisation and protein digestibility in tilapia $\left.{ }^{(5,11,12)}\right)$. The pelleted diets (Table 1 ) were produced by a small pellet mill to minimise the impact of mixing and granulation (high temperature process) on phytase activity. The enzymatic activity of phytase supplemented in feed was checked before and after the feeding period according to the method of Engelen et al. ${ }^{(30)}$.

Table 1. Diet formulations and their chemical compositions

\begin{tabular}{|c|c|c|}
\hline & Diet 1 & Diet 2 \\
\hline Ingredients (\%) & Control & Microbial phytase \\
\hline Fishmeal & $20 \cdot 0$ & $20 \cdot 0$ \\
\hline Rapeseed meal & $39 \cdot 0$ & $39 \cdot 0$ \\
\hline Indian rapeseed meal & $12 \cdot 0$ & $12 \cdot 0$ \\
\hline Bentonite & $1 \cdot 20$ & $1 \cdot 18$ \\
\hline Feed adhesives & 0.20 & $0 \cdot 20$ \\
\hline Soyabean oil & $2 \cdot 00$ & $2 \cdot 00$ \\
\hline $\mathrm{Ca}\left(\mathrm{H}_{2} \mathrm{PO}_{4}\right)_{2}$ & 1.00 & 1.00 \\
\hline Vitamin C phosphate & 0.05 & 0.05 \\
\hline Choline chloride & 0.20 & 0.20 \\
\hline Mineral premix* & $0 \cdot 10$ & $0 \cdot 10$ \\
\hline Vitamin premix* & $0 \cdot 10$ & 0.10 \\
\hline Antioxidants & 0.05 & 0.05 \\
\hline Fungicides & $0 \cdot 10$ & 0.10 \\
\hline Maize & 24.00 & 24.00 \\
\hline Microbial phytase $(5 \mathrm{U} / \mathrm{mg})$ & 0 & 0.02 \\
\hline \multicolumn{3}{|c|}{ Proximate chemical composition } \\
\hline Crude protein (\%) & $35 \cdot 36$ & $35 \cdot 71$ \\
\hline Crude lipid (kJ/g) & 5.98 & $5 \cdot 90$ \\
\hline \multicolumn{3}{|l|}{ Mineral analysis } \\
\hline $\mathrm{P}(\%)$ & 1.91 & 2.04 \\
\hline Phytate-P† & 0.342 & 0.342 \\
\hline Gross energy $(\mathrm{kJ} / \mathrm{g})$ & $17 \cdot 60$ & 18.53 \\
\hline
\end{tabular}

* National Research Council ${ }^{(29)}$

† The phytate-P was estimated by the generally known phytate-P content in maize $(0.15 \%)$ and rapeseed meal $(0.6 \%)$

\section{Fish husbandry}

In total, 120 healthy tilapia were acclimated for 1 month before the experiment. After the acclimation period, tilapia (19.3 (sE 0.02) g) were weighed and randomly distributed to two experimental groups with four replicates, and then reared for 12 weeks in cages $(3 \times 3 \times 2 \mathrm{~m})$. Fish were hand-fed to apparent satiation twice a day for 12 weeks. The feeding rate was approximately $3 \%$ at the beginning of the trial, and thereafter was increased weekly by weighing all fish in one cage per treatment. At each meal, fish in each cage were fed multiple times until apparent satiation within $30 \mathrm{~min}$, with no or negligible remains. Water quality parameters were checked each day. Temperature was in the range of $27 \cdot 1-36 \cdot 5^{\circ} \mathrm{C}$ and $\mathrm{pH}$ was 7.6 (sE 0.1); ammonia and nitrite-nitrogen were maintained under $0.2 \mathrm{mg} \mathrm{N} / 1$ and $0.05 \mathrm{mg} \mathrm{N} / \mathrm{l}$, respectively. At the end of the experiment, the fish were fasted for $24 \mathrm{~h}$ before sampling and harvest. All experimental and animal care procedures were approved by Feed Research Institute of Chinese Academy of Agricultural Sciences Animal Care Committee, under the auspices of the China Council for Animal Care (assurance no. 2009-HSX01). MS-222 was used as the anaesthetic. The field study was conducted in a private aquaculture pond with the owner's permission.

\section{Production and phosphorus utilisation}

Total number and body weight of fish in each cage were measured at the beginning and at the end of the 12-week feeding period. Weight gain (WG), food conversion ratio (FCR) and survival rate were assessed using the following formulae:

$$
\begin{aligned}
& \text { WG }(\mathrm{g}) \text { = final weight }- \text { initial weight } \\
& \text { FCR = total feed intake }(\mathrm{g}) / \text { total wet WG }(\mathrm{g}) \text {. }
\end{aligned}
$$

Fish were killed using $25 \mathrm{mg} / \mathrm{l}$ of tricaine methanesulphonate (MS-222) before sampling. Bone and scale samples were obtained from killed fish. Bones from ten fish were collected, boiled in de-ionized water for $2 \mathrm{~min}$ and cleaned thoroughly to remove soft tissues. Scales were collected from both lateral surfaces of ten fish and mucus was wiped off. Next, three samples were randomly chosen and pooled as one sample. All samples were maintained at $-70^{\circ} \mathrm{C}$ before analysis ${ }^{(31)}$. Total $\mathrm{P}$ in feed, bone and scale samples were determined using the vanadium-molybdate method according to the modified Association of Official Analytical Chemists (AOAC) method 986.11. The absorbance was measured at $640 \mathrm{~nm}$ using a UV-Vis spectrophotometer (Specord S100; Carl Zeiss) ${ }^{(24)}$. The phytate-P in feed was estimated by the generally known phytate-P content in rapeseed meal (0.6\%) and maize (0.15\%).

\section{Gut histology}

Intestinal samples from three fish per cage $(n 8)$ were obtained and fixed using $2.5 \%$ glutaraldehyde for scanning electron microscopy (SEM) studies, according to the method described by Merrifield et al. $^{(32)}$. Micrographs (magnification 100x) were used to observe the intestinal mucosa folds, and SEM micrographs (magnification $20000 \times$ ) were analysed to measure 
microvilli length ${ }^{(33)}$. SEM micrographs were analysed using ImageJ 1.36 (National Institutes of Health).

\section{Gut-adhesive bacteria}

Three cages of each group were randomly selected and three fish per cage were dissected under MS-222 (25 mg/l) anaesthesia. Intestines were aseptically removed, opened and gently agitated three times for $1 \mathrm{~min}$ in PBS to remove the contents and then pooled to investigate gut-adhesive bacteria $^{(34)}$. Genomic DNA was obtained using the extraction method as described by He et al. ${ }^{(35)}$ with some modifications. In brief, $200 \mathrm{mg}$ tissue samples were homogenised in $500 \mathrm{ml}$ lysozyme lysis buffer (0.3 $\mathrm{m}$-sucrose, $0.025 \mathrm{~m}$-EDTA, 0.025 $\mathrm{m}$-Tris-HCl, pH 8.0) and incubated at $37^{\circ} \mathrm{C}$ for $1 \mathrm{~h}$. The samples were gently inverted every $15 \mathrm{~min}$. Next, $1 \mathrm{ml}$ CTAB lysis buffer $(0 \cdot 1 \mathrm{M}$-Tris- $\mathrm{HCl}$, $0 \cdot 1 \mathrm{~m}$-Na-EDTA, $1.5 \mathrm{~m}-\mathrm{NaCl}, 1 \%$ CTAB, $2 \%$ SDS, pH $8 \cdot 0$ ) was added, and the samples were further incubated at $65^{\circ} \mathrm{C}$ for $4 \mathrm{~h}$, with gentle inversion every $15 \mathrm{~min}$. After incubation, the samples were centrifuged at $13000 \mathrm{~g}$ for $10 \mathrm{~min}$. The supernatant was transferred to sterilised tubes and an equal volume of trichloromethane was added, followed by gentle inversion and centrifugation at $13000 \boldsymbol{g}$ for $10 \mathrm{~min}$. The supernatant was transferred into a new tube and gently mixed with equal volume of isopropanol and precipitated at $-20^{\circ} \mathrm{C}$ for $30 \mathrm{~min}$, followed by centrifugation at $13000 \boldsymbol{g}$ for $10 \mathrm{~min}$. The pellet was collected, washed with $75 \%$ ethanol and re-suspended in $50 \mu \mathrm{l}$ double-distilled water. Genomic DNA was thereafter purified using a TIANquick Midi purification kit (TIANGEN).

The V3 region of the $16 \mathrm{~S}$ ribosomal RNA (rRNA) gene was amplified with primers 338-GC-f and 519-r (Table 2). PCR-DGGE (denaturing gradient gel electrophoresis) was performed according to Liu et al. ${ }^{(36)}$ and Zhou et al. ${ }^{(37)}$ using a DCode universal Mutation System (Bio-Rad). Purified PCR products were loaded onto denaturing gradient gels ranging from 40 to $60 \%$ polyacrylamide, and then electrophoresis was carried out at a constant voltage of $60 \mathrm{~V}$ for $16 \mathrm{~h}$ in $1 \times$ Trisacetate-EDTA buffer at $60^{\circ} \mathrm{C}$. The gels were stained in ethidium bromide solution $(0.5 \mathrm{mg} / \mathrm{ml}$ in Tris-acetate-EDTA buffer), destained in distilled water for $20 \mathrm{~min}$ and viewed under UV transillumination. The dominant bands were excised, reamplified, purified (TIANquick Midi purification kit; TIANGEN) and sequenced. Computer-assisted comparison of DGGE patterns was performed with Quantity One version 4.62 (Bio-Rad).

\section{Expression of hsp70 and immune-related cytokine genes}

The intestinal expression of $h s p 70$ and immune-related cytokine genes was assessed. Intestinal tissues were sampled from three fish per cage at the end of the 12-week feeding period. All the tissues from the same group were pooled and frozen in liquid $\mathrm{N}_{2}$ and stored at $-70^{\circ} \mathrm{C}$. Total RNA was extracted using a TRIzon Reagent RNA kit (Promega). The integrity of total RNA was verified by visualisation on $1.2 \%$ agarose gel. RNA was dissolved in $50 \mathrm{ml}$ RNase-free water and stored at $-70^{\circ} \mathrm{C}$ until use. Complementary DNA (cDNA) was synthesised for quantitative RT PCR (RT-qPCR) using the ReverTra Ace-a-RT-PCR kit (Toyobo).The qPCR primers were referenced from Liu et al. ${ }^{(38)}$ (Table 2). A sample of $2 \mu \mathrm{l}$ of cDNA was amplified by forty cycles in a $20-\mu$ l reaction system with the SYBR Green Premix Ex $\mathrm{Taq}^{\mathrm{TM}}$ II (TaKaRa) in an iQ5 multicolour real-time PCR detection system (Bio-Rad). The PCR conditions were as follows: $95^{\circ} \mathrm{C}$ for $3 \mathrm{~min}$, forty cycles $\left(95^{\circ} \mathrm{C} 20 \mathrm{~s}, 58^{\circ} \mathrm{C} 20 \mathrm{~s}\right.$ and $72^{\circ} \mathrm{C}$ $20 \mathrm{~s}$ ), and an additional final extension at $72^{\circ} \mathrm{C}$ for $10 \mathrm{~min}$. Data analysis was conducted using the $2^{-\Delta \Delta C_{T}}$ method. $\beta$-Actin and $18 \mathrm{~S}$ rRNA were used as the reference genes. All real-time PCR were performed at least three times and data were analysed using Bio-Rad iQ5 software.

\section{Statistical analysis}

Results are expressed as mean values with their standard errors. Statistical analyses were performed using GraphPad Prism 5. Differences between means were subjected to Student's $t$ test and were considered significant when probability $(P)$ values $<0.05$ were obtained. Cluster analysis was based on the unweighted pair group method using the arithmetic mean algorithm (UPGMA). Similarity between bacterial communities was evaluated with a pairwise similarity coefficient (Cs, the measure of the similarity of two samples by UPGMA): $<0 \cdot 60$

Table 2. Primers used in this study

\begin{tabular}{|c|c|c|c|}
\hline Gene name & Primers $\left(5^{\prime}-3^{\prime}\right)$ & Product size (bp) & GenBank (accession no.) \\
\hline $16 S$ rRNA & $\begin{array}{l}\text { F: CGCCCGCCGCGCGCGGCGGGCGGGGCG } \\
\text { GGGGCACGGGGGGACTCCTACGGGAGGCAGCAG } \\
\text { R: GTATTACCGCGGCTGCTG }\end{array}$ & & $\mathrm{N} / \mathrm{A}$ \\
\hline$\beta$-Actin & $\begin{array}{l}\text { F: GCTACTCCTTCACCACCACAG } \\
\text { R: CGTCAGGCAGCTCGTAACTC }\end{array}$ & 144 & JQ619775 \\
\hline $18 S$ rRNA & $\begin{array}{l}\text { F:CGATGCTCTTAGCTGAGTGT } \\
\text { ACGACGGTATCTGATCGTCT }\end{array}$ & 260 & JQ619778 \\
\hline tnf-a & $\begin{array}{l}\text { F: CTTCCCATAGACTCTGAGTAGCG } \\
\text { R: GAGGCCAACAAAATCATCATCCC }\end{array}$ & 161 & JF957372 \\
\hline$i l-1 \beta$ & $\begin{array}{l}\text { F: TGCACTGTCACTGACAGCCAA } \\
\text { R:ATGTTCAGGTGCACTTTGCGG }\end{array}$ & 112 & JF957368 \\
\hline hsp70 & $\begin{array}{l}\text { F: TGCCTTTGTCCAGACCGTAG } \\
\text { R: GTGTCCAACGCTGTCATCAC }\end{array}$ & 150 & JF957366 \\
\hline $\operatorname{tg}-\beta$ & $\begin{array}{l}\text { F: TGCGGCACCCAATCACACAAC } \\
\text { R: GTTAGCATAGTAACCCGTTGGC }\end{array}$ & 105 & JF957371 \\
\hline
\end{tabular}

rRNA, ribosomal RNA. 
were regarded as different, those with $0.60 \leq C s<0.80$ were considered to be marginally different and those with $C s \geq 0 \cdot 80$ were considered to be similar ${ }^{(39)}$.

\section{Results}

\section{Production and phosphorus utilisation}

WG and feed utilisation are displayed in Table 3. There were no significant differences between the two experimental groups $(P>0.05)$. Feed used for the two groups had equal amounts of total $\mathrm{P}$ and phytate-P (Table 1). After the 12-week feeding period, the scale $\mathrm{P}$ content of tilapia was significantly higher than control $(P<0.05)$ in the microbial phytase group, whereas bone $\mathrm{P}$ content was not influenced by phytase supplementation (Table 3).

\section{Gut histology}

SEM images showed that the arrangement of the intestinal mucosa folds in tilapia fed microbial phytase was more regular and tighter compared with the control (online Supplementary Fig. S1). The gut microvilli was significantly shorter $(P<0.05)$ but the microvilli density was higher $(P<0.05)$ in the microbial phytase group compared with the control (Table 4; online Supplementary Fig. S2).

\section{Gut-adhesive bacteria}

The 16S rRNA gene V3 PCR-DGGE fingerprints of the gut-adhesive bacterial communities for the two experimental groups are shown in Fig. 1. Different band patterns can be

Table 3. Growth-related parameters, survival rate and the percentage of phosphorus in bones and scales of tilapia fed the two experimental diets at the end of the feeding period

(Mean values with their standard errors)

\begin{tabular}{|c|c|c|c|c|}
\hline \multirow[b]{2}{*}{ Parameters } & \multicolumn{2}{|c|}{ Control } & \multicolumn{2}{|c|}{ Microbial phytase } \\
\hline & Mean & SE & Mean & SE \\
\hline IBW (g) & $19 \cdot 25$ & 0.06 & $19 \cdot 24$ & 0.06 \\
\hline FBW $(\mathrm{g})$ & 281.44 & 14.46 & 287.02 & 11.32 \\
\hline WG (g) & 261.98 & $7 \cdot 22$ & $267 \cdot 78$ & $5 \cdot 64$ \\
\hline FCR & 0.94 & 0.05 & 0.92 & 0.03 \\
\hline $\mathrm{P}$ in bones $(\%)$ & 5.43 & 0.88 & 4.42 & 0.41 \\
\hline $\mathrm{P}$ in scales $(\%)$ & 32.89 & $0 \cdot 1$ & $33.88^{*}$ & 0.36 \\
\hline
\end{tabular}

IBW, initial body weight; FBW, final body weight; WG, weight gain; FCR, feed conversion ratio.

${ }^{\star} P<0.05$ (Student's $t$ test).

Table 4. Intestinal microvilli length (by estimate) and density of tilapia fed the two experimental diets at the end of the feeding period (Mean values with their standard errors)

\begin{tabular}{llllll}
\hline & \multicolumn{2}{l}{ Microvilli length $(\mu \mathrm{m})$} & & \multicolumn{2}{c}{ Microvilli density $\left(\mu \mathrm{m}^{-2}\right)$} \\
\cline { 2 - 3 } \cline { 6 - 6 } Groups & Mean & SE & & Mean & SE \\
\hline Control & 1.13 & 0.01 & & 64.67 & 3.06 \\
Microbial phytase & $0.99^{*}$ & 0.06 & & $75.33^{*}$ & 5.03 \\
\hline
\end{tabular}

${ }^{*} P<0.05$ (Student's $t$ test).

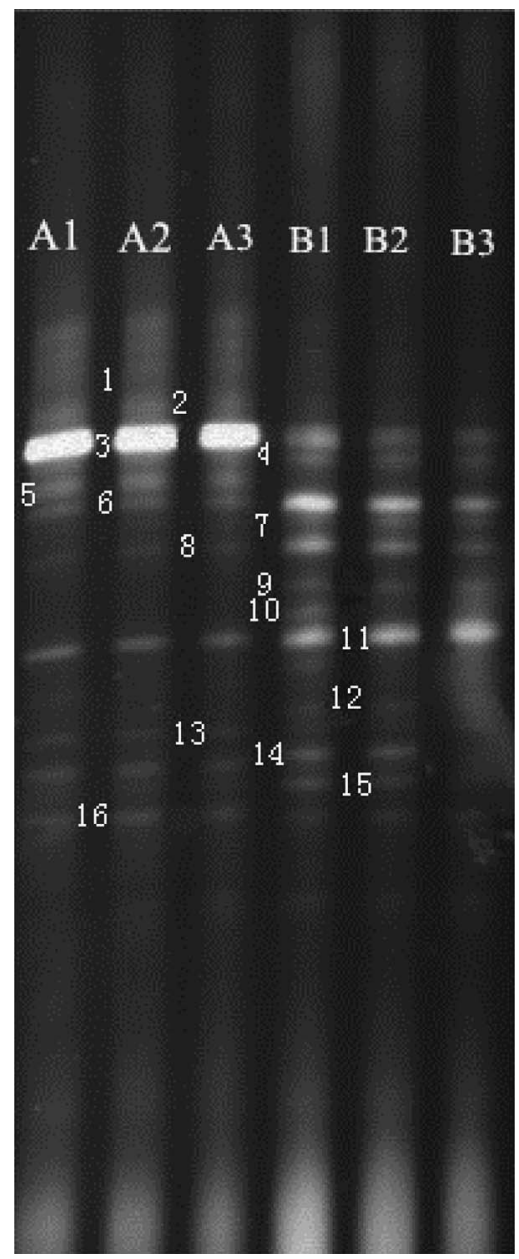

Fig. 1. 16S ribosomal RNA gene V3 PCR-DGGE fingerprints of the gutadhesive bacterial communities in tilapia of the control group and the microbial phytase group. A1, A2, A3: the control group; B1, B2, B3: the microbial phytase group. Number means different replicates.

visually recognised. Closest relatives of representative bands in the PCR-DGGE fingerprints are illustrated in Table 5. Bands 1, 3, 5, 6, 7 and 15 showed high similarity (98-100\%) with uncultured bacteria, in which bands 1 and 3 represent the most predominant intestinal-adhesive bacteria in the control group, with the average relative abundance of 17.0 and $27.6 \%$, respectively. The relative abundances of bands 1 and 5 were drastically reduced or even disappeared in the phytasesupplemented group $v$. control, whereas the abundances of bands 3 and band 6 showed a moderate decrease and increase, respectively $(P<0 \cdot 01)$. Meanwhile, band 11 , with $99 \%$ similarity to Vibrio sp., and band 8, with $99 \%$ similarity to Thermus sp., showed significant increases $(P<0.05)$ in the phytasesupplemented group compared with control, whereas the intensity of band 16, with $99 \%$ similarity to Exiguobacterium sp., significantly decreased. Bands 4, 9 and 12 were unique in the microbial phytase group, and were identified as Vibrio sp., Clostridium sp. and uncultured proteobacterium, respectively. At the phylum level, the collective abundance of bands belonging to Firmicutes and Thermus was significantly elevated by microbial phytase supplementation $(P<0.01$ for Thermus, 
Table 5. Representatives of the predominant gut-adhesive bacterial types in tilapia fed the two experimental diets as determined by the $16 \mathrm{~S}$ ribosomal DNA V3 DGGE fingerprints

(Mean values with their standard errors)

\begin{tabular}{|c|c|c|c|c|c|c|c|}
\hline \multirow[b]{3}{*}{ Phylum } & \multirow[b]{3}{*}{ Band no. } & \multirow[b]{3}{*}{ Closest relative (accession no.) } & \multirow[b]{3}{*}{ Identity (\%) } & \multicolumn{4}{|c|}{ Relative abundance (\%) } \\
\hline & & & & \multicolumn{2}{|c|}{ Control } & \multicolumn{2}{|c|}{ Microbial phytase } \\
\hline & & & & Mean & SE & Mean & SE \\
\hline \multirow[t]{5}{*}{ Proteobacteria } & & & & $16 \cdot 29$ & $1 \cdot 14$ & 33.89 & 7.49 \\
\hline & 2 & Bacterium fjat-scb-13 (HQ873719.1) & 100 & 7.65 & 1.04 & 1 & 1 \\
\hline & 10 & Beta proteobacterium (GU213375.1) & 99 & 0 & & 1.44 & 1.44 \\
\hline & 11 & Vibrio sp. (FJ457375.1) & 99 & 8.63 & 0.24 & $23 \cdot 00^{*}$ & 4.7 \\
\hline & 12 & Uncultured proteobacterium (HM448189.1) & 99 & 0 & & 8.45 & $2 \cdot 73$ \\
\hline \multirow[t]{3}{*}{ Firmicutes } & & & & $7 \cdot 11$ & 0.53 & $11.55^{\star}$ & 0.89 \\
\hline & 9 & Clostridium sp. (DQ839150.1) & 97 & 0 & & 6.86 & 0.98 \\
\hline & 16 & Exiguobacterium sp. (HQ418495) & 99 & $7 \cdot 11$ & 0.53 & $4.69^{*}$ & 0.43 \\
\hline \multirow[t]{3}{*}{ Actinobacteria } & & & & $10 \cdot 95$ & $1 \cdot 13$ & 8.52 & 0.96 \\
\hline & 13 & Saccharopolyspora pogona (DQ069279.1) & 93 & 4.23 & 0.29 & 2.02 & 2.02 \\
\hline & 14 & Brachybacterium sp. (HQ455045.1) & 100 & 6.72 & 0.86 & 6.5 & 1.08 \\
\hline \multirow[t]{3}{*}{ Thermus } & & & & $5 \cdot 8$ & 0.42 & $15 \cdot 02^{\star \star}$ & 1.61 \\
\hline & 4 & Thermus sp. (GQ853550.1) & 100 & 0 & & 5.79 & 0.62 \\
\hline & 8 & Thermus sp. (GQ853550.1) & 99 & $5 \cdot 8$ & 0.42 & $9 \cdot 22^{*}$ & $1 \cdot 21$ \\
\hline \multirow[t]{7}{*}{ Uncultured bacterium } & & & & $59 \cdot 85$ & 0.58 & $31.03^{*}$ & 1.75 \\
\hline & 1 & Uncultured bacterium (EU085537.1) & 99 & 17 & $5 \cdot 2$ & 3.27 & 3.27 \\
\hline & 3 & Uncultured bacterium (EU697160.) & 100 & $27 \cdot 6$ & 2.04 & $10 \cdot 31^{\star \star}$ & 1.95 \\
\hline & 5 & Uncultured bacterium (FJ235654.1) & 100 & 7.06 & 0.18 & 0 & \\
\hline & 6 & Uncultured bacterium (AJ851120.1) & 100 & 8.19 & 0.78 & $14 \cdot 16^{\star *}$ & $1 \cdot 1$ \\
\hline & 7 & Uncultured organism (GU972317.1) & 98 & 0 & & 1.62 & 1.62 \\
\hline & 15 & Uncultured bacterium (HM172674.1) & 100 & 0 & & 1.66 & 1.66 \\
\hline
\end{tabular}

${ }^{*} P<0.05,{ }^{* *} P<0.01$ (Student's $t$ test).

$P<0.05$ for Firmicutes), whereas no significant difference was observed for the collective richness of both Proteobacteria and Actinobacteria. Both the cluster analysis (Fig. 2) and pairwise CS matrix (Table 6) indicated significant influence of microbial phytase supplementation on gut-adhesive bacterial communities $(C s<0 \cdot 60)$.

\section{Expression of hsp70 and immune-related cytokine genes}

The relative expressions of gut immune-related cytokine genes (tnf- $\alpha, i l-1 \beta$ and $\operatorname{tg} f-\beta$ ) and $h s p 70$ were tested to evaluate the influence of microbial phytase supplementation on gut immunity and stress status of tilapia. The gut inflammatory responses were stimulated in the microbial phytase supplementation group, as indicated by the up-regulation of tnf- $\alpha$ and $\operatorname{tg} f-\beta$ (Fig. 3). The relative expression of $h s p 70$ showed approximately 6-fold increase in the microbial phytase group compared with control $(P<0.05)$, indicating an elevated gut stress status by the microbial phytase.

\section{Discussion}

Studies about microbial phytase supplementation in diets for fish have mainly focused on the effect on nutrient utilisation and fish growth performance ${ }^{(5,6,9,11,12,23)}$. No study has investigated the effect of microbial phytase on gut health of fish, which is important for fully evaluating the outcomes of phytase supplementation. In this study, the impact of microbial phytase on gut health of fish was evaluated, focusing on the effect on

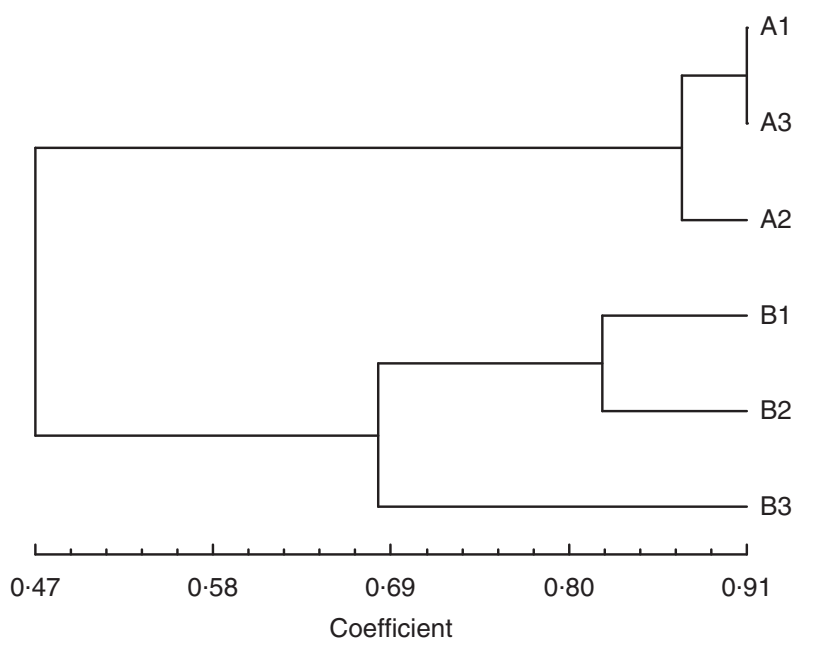

Fig. 2. Cluster analysis of the gut-adhesive bacterial communities in tilapia of the control and microbial phytase groups based on 16S ribosomal RNA gene V3 DGGE fingerprints. A1, A2, A3: the control group; B1, B2, B3: the microbial phytase group.

Table 6. Pairwise similarity coefficients matrix for the gut-adhesive bacterial communities of tilapia fed the two experimental diets at the end of the feeding period

\begin{tabular}{lllllll}
\hline & A1 & A2 & A3 & B1 & B2 & B3 \\
\hline A1 & 1.00 & & & & & \\
A2 & 0.85 & 1.00 & & & & \\
A3 & 0.91 & 0.89 & 1.00 & & & \\
B1 & 0.54 & 0.49 & 0.54 & 1.00 & & \\
B2 & 0.43 & 0.47 & 0.44 & 0.82 & 1.00 & \\
B3 & 0.41 & 0.45 & 0.43 & 0.62 & 0.74 & 1.00 \\
\hline
\end{tabular}



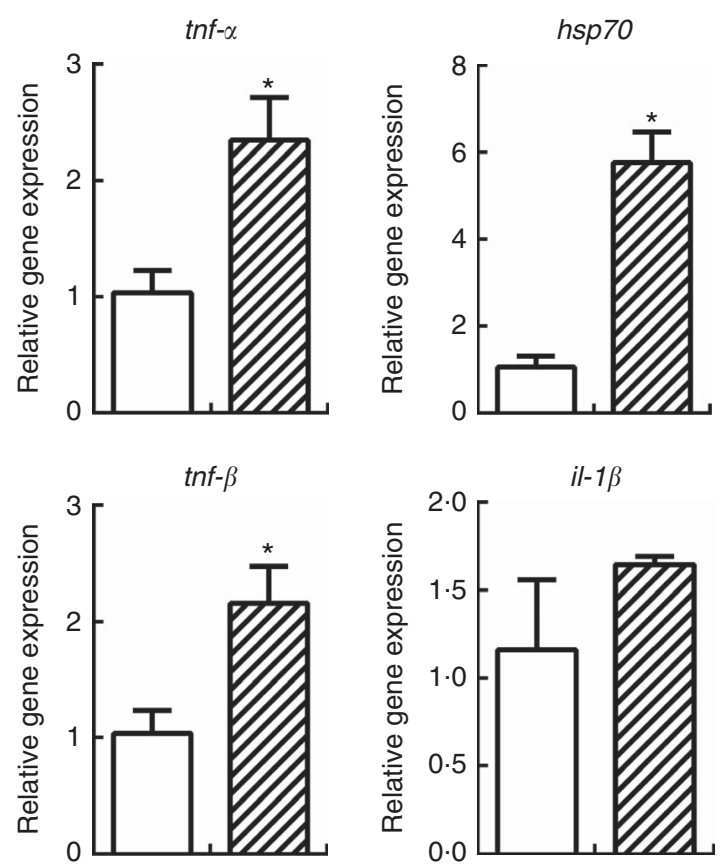

Fig. 3. Effects of dietary microbial phytase on intestinal cytokine gene expressions in tilapia at the end of the 12-week feeding period. Values are means $(n 4)$, with standard errors represented by vertical bars. ${ }^{*} P<0.05$ (Student's $t$ test). $\square$, Control; $\mathbb{Z}$, microbial phytase.

intestinal histology, adhesive microbiota as well as the stress and inflammation status in the gut.

Both dietary groups grew well with high body WG after 12 weeks of feeding and there were no deaths throughout the experiment in both groups. Microbial phytase supplementation at $1000 \mathrm{U} / \mathrm{kg}$ did not improve tilapia's production at a statistically significant level, and only a trend of improvement was observed. However, positive impacts of dietary microbial phytase on tilapia growth have been reported before. Diets with $1000 \mathrm{U} / \mathrm{kg}$ phytase supplementation can significantly improve growth of Nile tilapia $^{(23)}$. Moreover, Cao et al. ${ }^{(13)}$ reported that pre-treatment of plant ingredients with phytase at $1000 \mathrm{U} / \mathrm{kg}$ had significantly positive effects on growth performance in Nile tilapia. The discrepancy of our result with previous ones might be attributed to the differences in the basal diet formulation, source of microbial phytase as well as rearing conditions compared with previous studies ${ }^{(11)}$. Our preliminary 4 -week feeding experiment in tilapia, with diets supplemented with currently used microbial phytase at 0, 500, 1000, 2000 and $4000 \mathrm{U} / \mathrm{kg}$, showed that only the dose of $1000 \mathrm{U} / \mathrm{kg}$ resulted in a trend in growth improvement and higher doses showed decreased growth compared with $1000 \mathrm{U} / \mathrm{kg}$ (data not shown here). Therefore, the dose effect should not be a factor responsible for the observed insignificant improvement in growth performance of tilapia.

Furuya et al. ${ }^{(11)}$ observed that phytase supplementation between 500 and 1500 phytase units/kg improved P availability for tilapia. Portz \& Liebert ${ }^{(23)}$ reported that microbial phytase supplementation may improve $\mathrm{P}$ content in the vertebra and scales of tilapia. In our study, the P content in bones was not affected by phytase, but there was a significantly higher level of $\mathrm{P}$ content in the scales of tilapia fed the microbial phytase diet.
As we know, P level in scales but not in the vertebrae was more sensitive to dietary $\mathrm{Ca}^{(40)}, \mathrm{Cd}^{(41)}$ and also other elements ${ }^{(42,43)}$. Moreover, scales are the source of reserve $\mathrm{P}$ in fish. Available $\mathrm{P}$ is first utilised by the bone for proper mineralisation and then utilised for scale growth and storage. Scale P appears to be easily mobilised for utilisation in the body when needed and is closely related to dietary $\mathrm{P}$ status ${ }^{(31)}$. Therefore, these results indicate the efficiency of the microbial phytase to improve $P$ bioavailability in our study.

The effects of phytase supplementation on gut bacteria of fish are largely unknown, despite their critical role in host nutrition, health and production ${ }^{(44)}$. In this study, a significant impact of microbial phytase on the gut microbial community was noted based on 16S rRNA gene DGGE fingerprints. Evidences suggest that diet composition is a strong modulator of host gut microbial composition $^{(45)}$. Therefore, the influence of phytase on the gut microbiota might be due to the increased supply of dissolved $\mathrm{P}$ and other nutrients by the hydrolysis of phytate ${ }^{(6)}$. The relative abundance of Clostridium sp. and Thermus sp. was significantly stimulated by microbial phytase supplementation. Notably, Clostridium sp. may ferment carbohydrates into SCFA such as butyrate and propionate, which play an important role as fuel for intestinal epithelial cells ${ }^{(44,46)}$ and anti-inflammatory factors $^{(47)}$. Similar to our result, Smulikowska et al. ${ }^{(26)}$ reported that the villus length and crypt depth in the jejunum and ileum of broiler chicken were increased by dietary phytase supplementation, and they attributed these effects to the higher production of SCFA due to the modulation of gut microbiota and the increase in their metabolic activity.

In this study, the microvillus length and density were used as the morphology parameters to evaluate intestinal health. The gut mucosa microvilli densities were significantly enhanced by phytase supplementation. However, gut microvilli length was inhibited, indicating that microbial phytases have both beneficial and detrimental effects on gut morphology.

Heat shock protein 70 ( $h s p 70)$ played essential roles in protein metabolism under normal and stress conditions, including de novo protein folding, membrane translocation, degradation of misfolded proteins and other regulatory processes ${ }^{(48,49)}$. The expression of $h s p 70$ gene was used as the biomarker of host stressful conditions in certain organs ${ }^{(50)}$. Inflammatory cytokines including $i l-1 \beta$, tnf- $\alpha$ (pro-inflammatory factors) ${ }^{(51)}$ and $\operatorname{tg} f-\beta$ (anti-inflammatory factor) ${ }^{(52)}$ are important mediators of inflammation released by activated phagocytes and are commonly used as reference genes in studies of inflammatory status. The expression of $b s p 70$ in the kidney of tilapia was significantly reduced $(P<0.05)$ in the phytase group (online Supplementary Fig. S4), which may reflect a general improved welfare of fish fed microbial phytase. However, the expressions of $h s p 70, t n f-\alpha$ and $\operatorname{tg} f-\beta$ in the gut of tilapia were increased (Fig. 3 ), which revealed a higher gut stress and inflammatory status induced by microbial phytase. To our knowledge, this is the first report to show that phytase supplementation may lead to enhanced inflammation and stress in the gut of fish, which might act as an additional reason contributing to the failure of phytase to improve the overall growth performance of tilapia in this study, as the increased energy expenditure caused by gut inflammation ${ }^{(53)}$ might counteract the positive effects of dietary 
microbial phytase on growth. In addition, the enhanced gut inflammation status might be responsible for the decreased microvilli length.

Taken together, this microbial phytase exerted mixed effects on tilapia in terms of gut health, that is, improved microvilli density $v$. reduced microvilli length and higher stress/inflammation status in the gut. The negative effects of phytase might be due to the following reasons: (1) the direct adverse impacts to host fish by this microbial phytase or/and (2) the indirect effects to host fish by the change in gut microbiota induced by the dietary phytase. As mentioned above, the enrichment of Clostridium sp. in the gut microbiota of fish fed phytase may implicate an elevated SCFA level in the gut, which should benefit the gut morphology ${ }^{(44,46)}$ and inflammatory status ${ }^{(47)}$. Therefore, the indirect effect mediated by change in microbiota was putatively beneficial, and the observed adverse impacts were probably attributed to the direct effect of microbial phytase on the host, which deserves further investigation by experiments in germ-free fish models.

Some exogenous enzymes may exert adverse effects on fish production. Kazerani et al. ${ }^{(54)}$ observed a dose-dependent reduction in the growth performance of common carp (Cyprinuscarpio) fed commercial exogenous multienzymes containing xylanase and $\beta$-glucanase. The authors hypothesised that these exogenous enzymes may result in the production of galactose and xylose from dietary NSP in the intestine of fish, to which most fish species are intolerant to ${ }^{(55)}$. Similarly, Mahmoud et $a{ }^{(56)}$ observed that commercially prepared exogenous multienzyme preparations Pan Zyme (containing xylanase, acidic proteinase, neutral proteinase and cellulase) and Phytase-plus broiler 500 (containing phytase enzyme; Bytara) both reduced the production of Nile tilapia. The Pan Zyme group showed mild degeneration of intestinal mucosa as well as focal detachment of the epithelial lining, whereas Phytase-plus broiler 500 led to degeneration of intestinal mucosa and mild enteritis characterised by aggregation of mononuclear cells (mainly lymphocytes). In the present study, the microbial phytase reduced the intestinal microvilli height and increased the intestinal inflammation and stress status of host fish, which might be due to its antigenicity.

In conclusion, dietary microbial phytase may exert mixed effects on hybrid tilapia, and could guide our future selection of phytases as aquafeed additives, that is, eliminating those that can stimulate intestinal inflammation.

\section{Acknowledgements}

The authors are indebted to Lei Zhu's help throughout the feeding experiment. The authors are grateful to Yang Deng for his excellent technical assistance.

This work was supported by the National Natural Science Foundation of China (31272672, 31572633), the Key Project of Chinese National Programs for Fundamental Research and Development (973 Program) (2015CB150605), and Beijing earmarked fund for Modern Agro-industry Technology Research System (SCGWZJ 20151104-4).

The authors' contributions are as follows: J. H. performed all the data analysis and wrote a draft of the manuscript. Y. Y. and
Y. C. managed the feeding trial and cytokine gene expression analysis. S. H. completed the DGGE and electron microscopy analysis. X. Z. and Z. Z. designed and guided the experimental performance and helped in the writing of the manuscript. C. R. and $\mathrm{B}$. Y. improved the manuscript by critical comments and suggestions.

There are no conflicts of interest.

\section{Supplementary material}

For supplementary material/s referred to in this article, please visit http://dx.doi.org/doi:10.1017/S0007114516001240

\section{References}

1. Fontainhas-Fernandes A, Gomes E, Reis-Henriques MA, et al. (1999) Replacement of fish meal by plant proteins in the diet of Nile tilapia: digestibility and growth performance. Aquacult Int 7, 57-67.

2. Mbahinzireki GB, Dabrowski K, Lee KJ, et al. (2001) Growth, feed utilization and body composition of tilapia (Oreochromis $s p$.) fed with cottonseed meal-based diets in a recirculating system. Aquacult Nutr 7, 189-200.

3. Jackson LS, Li MH \& Robinson EH (1996) Use of microbial phytase in channel catfish Ictalurus punctatus diets to improve utilization of phytate phosphorus. $J$ World Aquacult Soc 27, 309-313.

4. Reddy NR, Sathe SK \& Salunkhe DK (1982) Phytates in legumes and cereals. Adv Food Res 28, 1-92.

5. Kumar V, Sinha AK, Makkar HPS, et al. (2012) Phytate and phytase in fish nutrition. J Anim Physiol Anim Nutr 96, 335-364.

6. Cao L, Wang WM, Yang CT, et al. (2007) Application of microbial phytase in fish feed. Enzyme Microb Technol $\mathbf{4 0}$, 497-507.

7. Schafer A, Koppe WM, Meyerburgdorff KH, et al. (1995) Effects of a microbial phytase on the utilization of native phosphorus by carp in a diet based on soybean-meal. Water Sci Technol 31, 149-155.

8. Vielma J, Lall SP, Koskela J, et al. (1998) Effects of dietary phytase and cholecalciferol on phosphorus bioavailability in rainbow trout (Oncorbynchus mykiss). Aquaculture 163, 309-323.

9. Sajjadi M \& Carter CG (2004) Dietary phytase supplementation and the utilisation of phosphorus by Atlantic salmon (Salmo salar L.) fed a canola-meal-based diet. Aquaculture 240, 417-431.

10. Ai QH, Mai KS, Zhang WB, et al. (2007) Effects of exogenous enzymes (phytase, non-starch polysaccharide enzyme) in diets on growth, feed utilization, nitrogen and phosphorus excretion of Japanese seabass, Lateolabrax japonicus. Comp Biochem Physiol A. Mol Integr Physiol 147, 502-508.

11. Furuya WM, Goncalves GS, Furuya VRB, et al. (2001) Phytase as feeding for Nile tilapia (Oreochromis niloticus). Performance and digestibility. Rev Bras Zootecn 30, 924-929.

12. Liebert F \& Portz L (2005) Nutrient utilization of Nile tilapia Oreochromis niloticus fed plant based low phosphorus diets supplemented with graded levels of different sources of microbial phytase. Aquaculture 248, 111-119.

13. Cao L, Yang Y, Wang WM, et al. (2008) Effects of pretreatment with microbial phytase on phosphorous utilization and growth performance of Nile tilapia (Oreochromis niloticus). Aquacult Nutr 14, 99-109. 
14. Van Weerd JH, Khalaf KA, Aartsen FJ, et al. (1999) Balance trials with African catfish Clarias gariepinus fed phytasetreated soybean meal-based diets. Aquacult Nutr 5, 135-142.

15. Papatryphon E \& Soares JH (2001) The effect of phytase on apparent digestibility of four practical plant feedstuffs fed to striped bass, Morone saxatilis. Aquacult Nutr 7, 161-167.

16. Debnath D, Sahu NP, Pal AK, et al. (2005) Present scenario and future prospects of phytase in aquafeed - review. Asian Austral J Anim 18, 1800-1812.

17. Sugiura SH, Gabaudan J, Dong FM, et al. (2001) Dietary microbial phytase supplementation and the utilization of phosphorus, trace minerals and protein by rainbow trout [Oncorbynchus mykiss (Walbaum)] fed soybean meal-based diets. Aquacult Res 32, 583-592.

18. Oliva-Teles A, Pereira JP, Gouveia A, et al. (1998) Utilisation of diets supplemented with microbial phytase by seabass (Dicentrarchus labrax) juveniles. Aquat Living Resour 11, 255-259.

19. Vielma J, Makinen T, Ekholm P, et al. (2000) Influence of dietary soy and phytase levels on performance and body composition of large rainbow trout (Oncorbynchus mykiss) and algal availability of phosphorus load. Aquaculture 183, 349-362.

20. Nwanna LC (2007) Effect of dietary phytase on growth, enzyme activities and phosphorus load of Nile tilapia (Oreochromis niloticus). J Franklin Inst 2, 972-976.

21. Baruah K, Sahu NP, Pal AK, et al. (2007) Dietary microbial phytase and citric acid synergistically enhances nutrient digestibility and growth performance of Labeo rohita (Hamilton) juveniles at sub-optimal protein level. Aquacult Res 38, 109-120.

22. Omogbenigun FO, Nyachoti CM \& Slominski BA (2003) The effect of supplementing microbial phytase and organic acids to a corn-soybean based diet fed to early-weaned pigs. J Anim Sci 81, 1806-1813.

23. Portz L \& Liebert F (2004) Growth, nutrient utilization and parameters of mineral metabolism in Nile tilapia Oreochromis niloticus (Linnaeus, 1758) fed plant-based diets with graded levels of microbial phytase. J Anim Physiol Anim Nutr (Berl) 88, 311-320.

24. Liebert F \& Portz L (2007) Different sources of microbial phytase in plant based low phosphorus diets for Nile tilapia Oreochromis niloticus may provide different effects on phytate degradation. Aquaculture 267, 292-299.

25. Nelson TS, Shieh TR, Wodzinski RJ, et al. (1971) Effect of supplemental phytase on the utilization of phytate phosphorus by chicks. J Nutr 101, 1289-1293.

26. Smulikowska S, Czerwinski J \& Mieczkowska A (2008) Effect of an organic acid blend and phytase added to a rapeseed cake-containing diet on performance, intestinal morphology, caecal microflora activity and thyroid status of broiler chickens. J Anim Physiol Anim Nutr (Berl) 94, 15-23.

27. Metzler-Zebeli BU, Vahjen W, Baumgartel T, et al. (2010) Ileal microbiota of growing pigs fed different dietary calcium phosphate levels and phytase content and subjected to ileal pectin infusion. J Anim Sci 88, 147-158.

28. Verdegem MCJ, Hilbrands AD \& Boon JH (1997) Influence of salinity and dietary composition on blood parameter values of hybrid red tilapia, Oreochromis niloticus (Linnaeus) $\mathrm{x}$ O. mossambicus (Peters). Aquacult Res 28, 453-459.

29. National Research Council (1993) Nutrient Requirements of Fish. Washington, DC: National Academies Press.

30. Engelen AJ, van der Heeft FC, Randsdorp $\mathrm{PH}$, et al. (1994) Simple and rapid determination of phytase activity. J AOAC Int 77, 760-764.
31. Hughes KP \& Soares JH (1998) Efficacy of phytase on phosphorus utilization in practical diets fed to striped bass Morone saxatilis. Aquacult Nutr 4, 133-140.

32. Merrifield DL, Dimitroglou A, Bradley G, et al. (2009) Soybean meal alters autochthonous microbial populations, microvilli morphology and compromises intestinal enterocyte integrity of rainbow trout, Oncorbynchus mykiss (Walbaum). J Fish Dis 32, 755-766

33. Fagundes-Neto U, De Martini-Costa S, Pedroso MZ, et al. (2000) Studies of the small bowel surface by scanning electron microscopy in infants with persistent diarrhea. BrazJMed Biol Res 33, 1437-1442.

34. Ringø E (1993)) The effect of chromic oxide (Cr2O3) on aerobic bacterial populations associated with the intestinal epithelial mucosa of Arctic charr, Salvelinus alpinus (L.). Can J Microbiol 39, 1169-1173.

35. He SX, Zhou ZG, Liu YC, et al. (2009) Effects of dietary Saccharomyces cerevisiae fermentation product (DVAQUA (R)) on growth performance, intestinal autochthonous bacterial community and non-specific immunity of hybrid tilapia (Oreochromis niloticus female x O. aureus male) cultured in cages. Aquaculture $\mathbf{2 9 4}$, 99-107.

36. Liu YC, Zhou ZG, Yao B, et al. (2008) Effect of intraperitoneal injection of immunostimulatory substances on allochthonous gut microbiota of Atlantic salmon (Salmo salar L.) determined using denaturing gradient gel electrophoresis. Aquacult Res 39, 635-646

37. Zhou ZG, He SX, Liu YC, et al. (2009) The effects of dietary yeast culture or short-chain fructo-oligosaccharides on the intestinal autochthonous bacterial communities in juvenile hybrid tilapia, Oreochromis niloticus female x Oreochromis aureus male. J World Aquacult Soc 40, 450-459.

38. Liu WS, Ren PF, He SX, et al. (2013) Comparison of adhesive gut bacteria composition, immunity, and disease resistance in juvenile hybrid tilapia fed two different Lactobacillus strains. Fish Shellfish Immunol 35, 54-62.

39. Wang W, Zhou Z, He S, et al. (2010) Identification of the adherent microbiota on the gills and skin of poly-cultured gibel carp (Carassius auratus gibelio) and bluntnose black bream (Megalobrama amblycephala Yib). Aquac Res $\mathbf{4 1}$, $72-83$.

40. Ye CX, Liu YJ, Tian LX, et al. (2006) Effect of dietary calcium and phosphorus on growth, feed efficiency, mineral content and body composition of juvenile grouper, Epinephelus coioides. Aquaculture 255, 263-271.

41. Berntssen MHG, Waagbø R, Toften H, et al. (2003) Effects of dietary cadmium on calcium homeostasis, Ca mobilization and bone deformities in Atlantic salmon (Salmo salar L.) parr. Aquacult Nutr 9, 175-183.

42. Lall SP (1989) The minerals. Fish Nutr 3, 219-257.

43. Lall SP \& Lewis-McCrea LM (2007) Role of nutrients in skeletal metabolism and pathology in fish - An overview. Aquaculture 267, 3-19.

44. Fuller R, Perdigón G, Fuller R, et al. (2005) Gut flora, nutrition, immunity and health. Int J Dairy Technol 58, 238.

45. Kiarie E, Romero LF \& Nyachoti CM (2013) The role of added feed enzymes in promoting gut health in swine and poultry. Nutr Res Rev 26, 71-88.

46. Vinolo MA, Rodrigues HG, Nachbar RT, et al. (2011) Regulation of inflammation by short chain fatty acids. Nutrients $\mathbf{3}$, 858-876.

47. Atarashi K, Tanoue T, Oshima K, et al. (2013) Treg induction by a rationally selected mixture of Clostridia strains from the human microbiota. Nature 500, 232-236. 
48. Iwama GK, Thomas PT, Forsyth RB, et al. (1998) Heat shock protein expression in fish. Rev Fish Biol Fisher $\mathbf{8}$, $35-56$.

49. Xing H, Li S, Wang X, et al. (2013) Effects of atrazine and chlorpyrifos on the mRNA levels of HSP70 and HSC70 in the liver, brain, kidney and gill of common carp (Cyprinus carpio L.). Chemosphere 90, 910-916.

50. Morimoto RI (1998) Regulation of the heat shock transcriptional response: cross talk between a family of heat shock factors, molecular chaperones, and negative regulators. Gene Dev 12, 3788-3796.

51. Kudo O, Fujikawa Y, Itonaga I, et al. (2002) Proinflammatory cytokine (TNF $\alpha / \mathrm{IL}-1 \boldsymbol{\alpha})$ induction of human osteoclast formation. J Pathol 198, 220-227.

52. Sano C, Shimizu T, Sato K, et al. (2000) Effects of secretory leucocyte protease inhibitor on the production of the anti-inflammatory cytokines, IL-10 and transforming growth factor-beta (TGF-beta), by lipopolysaccharidestimulated macrophages. Clin Exp Immunol 121, 77-85.

53. Qiu R, Croom J, Ali RA, et al. (2012) Direct fed microbial supplementation repartitions host energy to the immune system. J Anim Sci 90, 2639-2651.

54. Kazerani HR \& Shahsavani D (2011) The effect of supplementation of feed with exogenous enzymes on the growth of common carp (Cyprinus carpio). Iran J Vet Res 12, 127-132.

55. Stone DAJ, Allan GL \& Anderson AJ (2003) Carbohydrate utilization by juvenile silver perch, Bidyanus bidyanus (Mitchell). IV. Can dietary enzymes increase digestible energy from wheat starch, wheat and dehulled lupin? Aquacult Res 34, 135-147.

56. Mahmoud MMA, Kilany OE \& Dessouki AA (2014) Effects of fish meal replacement with soybean meal and use of exogenous enzymes in diets of Nile tilapia (Oreochromisniloticus) on growth, feed utilization, histopathological changes and blood parameters. Life Sci J 11, 6-18. 